\title{
Assessment of Physico-chemical Properties and Weed Dynamics of Dalpatsagar Reservoir, Jagdalpur
}

\author{
Subhash Soni*, A. Pradhan and Vikky Kumar
}

S. G. College of Agriculture \& Research Station, IGKV, Jagdalpur (C.G.), India

*Corresponding author

Ke y w o r d s
Physico-chemical
Properties,
Weed dynamics
Article Info
$\begin{aligned} & \text { Accepted: } \\ & 17 \text { October } 2020 \\ & \text { Available Online: } \\ & 10 \text { November } 2020\end{aligned}$

\section{A B S T R A C T}

Dalpatsagar reservoir is one of the oldest water bodies in Jagdalpur city at Bastar region of Chhattisgarh state. The water bodies is severely infested with different kind of aquatic weed species throughout the year since last decade and it modified the structure of habitat and influenced the aquatic organism. The physico-chemical properties of Dalpatsagar reservoir was changed with season year after year that influence the quality of water and pond ecosystem. The study was carried out at Dalpatsagar reservoir during June 2019 to May 2020 throughout the year. To assess the physico- chemical properties of pond water sample was collected from 11 different locations at Dalpatsagar reservoir. The physicochemical properties of Dalpatsagar reservoir was observed significantly varied with different season, the maximum value of $\mathrm{pH} 8.31$ and EC $0.47 \mathrm{dSm}^{-1}$ was recorded in summer season at site of Jhada Tarae (JT) while the minimum value of $\mathrm{pH} 7.13$ at the site of Mundra Dhipka (MD) and EC $0.21 \mathrm{dSm}^{-1}$ at Housing Board Drainage (HBD) was recorded during monsoon season. The value of TDS was highly varied with different season, the TDS was maximum $301.60 \mathrm{mg} / \mathrm{L}$ at Jhada Tarae (JT) in summer season while it is observed minimum 202.40 at Jhada Tarae (JT) during monsoon season. The amount of $\mathrm{CO}_{3}$ and $\mathrm{HCO}_{3} 81.76 \mathrm{mg} / \mathrm{L}$ and $306.61 \mathrm{mg} / \mathrm{L}$ respectively, was observed higher during winter season while it was minimum during summer season. Dalpatsagar reservoir was severely infested with 20 major aquatic weeds species out of them the 7 most dominant weed species are Eichhornia crassipes, Pistia stratiote, Ipomoea aquatica, Nelumbo nucifera, Alternanthera philoxeroides, Nymphaea rubra and Hydrilla verticillata were found throughout the year. The weed density and weed dry matter was observed monthly in throughout the year. The weed density plant $/ \mathrm{m}^{2}$ was observed higher with Hydrilla verticillata followed by Pistia stratiote and Eichhornia crassipes during September to January month while the weed dry weight $\mathrm{g} / \mathrm{m}^{2}$ was found higher with Eichhornia crassipes followed by Nelumbo nucifera and Nymphaea rubra at throughout the year.

\section{Introduction}

Wetland ecosystem is a natural ecosystem unit of water habitat which includes both
Biotic components and abiotic environment that influencing the properties of each other and both are necessary for the maintenance of aquatic life. It is also an essential part of 
biological diversity and ecosystem functioning and its utility performance varied by the hydrological and ecosystem functioning (Banner and MacKenzie, 2000). In open fresh water wetland, quality of water play primary and important role for survival of aquatic communities, in their water stability and its quality is varied due to variation in physico-chemical properties, because some change in quality of water directly or indirectly affects the pond ecosystem. The aquatic plants diversity is also associated with water quality and they influence the health of ponds ecosystem and economic development (Prakash and Somashekar, 2006). There are various parameters that operate in the freshwater wetland ecosystem and determine the health of the ecosystems are broadly as physical (temperature, density) and chemical $(\mathrm{pH}$, conductivity, TDS etc.). A detail study of these parameters will help in understanding the appropriate structural and functional aspects of an ecosystem. Physico-chemical properties such as temperature, $\mathrm{pH}$, electrical conductivity, TDS, $\mathrm{CO}_{3}$ and $\mathrm{HCO}_{3}$ content are known to operate in pond ecosystem, which play a significant role in the composition, distribution and abundance of aquatic macrophytes (Mustapha and Omotosho, 2005). Aquatic weed species Alternanthera philoxeroides, Chara spp., Ipomoea spp. Eichhornia crassipes, Hydrilla verticillata, Nelumbo nucifera, Nitella spp. Nymphaea stellata, Salvinia molesta, Typha angustata, Vallisnaria spp. are primary concern in Indian aquatic condition (Gopal and Sharma 1981). Among these, Eichhornia crassipes, alligator weed and lotus species of aquatic weeds are of primary concern in India and all over world. In general, it is estimated that $20-25 \%$ of the total utilizable water in India is currently infested with Eichhornia crassipes (water hyacinth), while in the state of Assam, Kerala, West Bengal, Orissa and Bihar, more than $40 \%$ water bodies are infested with water hyacinth (Sushilkumar 2011).

Dalpatsagar reservoir is one of the oldest freshwater body located in Jagdalpur city in Chhattisgarh state. The area of lake is expanding upto 340.44 acre in between $19^{\circ} 5^{\prime} 41^{\prime \prime} \mathrm{N}$ and $82^{\circ} 0^{\prime} 43^{\prime \prime} \mathrm{E}$. The lake is fairly rich with aquatic macrophytes Ipomoea aquatic, Oryza nivara, Oxalis carniculata, Ipomoea carnea, Typha augustata, Echinodorus grisebachii, Nymphaea alba, Nelumbo nucifera, Nymphaea rubra and Nymphaea indica (Pradhan and Patil, 2017). The physico-chemical properties of a Dalpatsagar lake is significantly changed by anthropogenic activity such as entry of domestic waste water, agricultural drainage water and by industrial waste water as well as natural dynamics which consequently affect the water quality, production capacity of pond, Distribution and abundance of aquatic weed species and disturbance in balance of ecological system operating in lake. Further, study on assessment of seasonal variation in physico-chemical properties for one year might reveal whether changes are seasonal fluctuations or due to other factors. Present study aims to investigate the seasonal variations of physico-chemical properties and associated weed flora at Dalpatsagar reservoir.

\section{Materials and Methods}

Fresh water body Dalpatsagar reservoir is situated at north-west part of Jagdalpur city in Chhattishgarh state, India in between $19^{\circ} 5^{\prime} 41^{\prime \prime} \mathrm{N}$ and $82^{\circ} 0^{\prime} 43^{\prime \prime} \mathrm{E}$ with elevation of $563 \mathrm{~m}$ MSL. The average annual rainfall of the area is $1400 \mathrm{~mm}$. the major amount of precipitation occurs between june to September (about 3 to 4 months) which is main source of water in aquatic water body. The average annual temperature is during experiment is between $25^{\circ} \mathrm{C}$ to $30^{\circ} \mathrm{C}$ and the 
hottest and coolest month was May and January respectively were recorded from meteorological observatory S.G. CARS Jagdalpur.

Sampling site was decided by considering the shallow and deep regions of the water body were must included. At Dalpatsagar reservoir, water and weed sample were collected from 11 different location and these sampling spots are locally named by fisherman as 1. Centre Temple (CT) 2. Shaan Baule (SB) 3. Bade Baule (BB) 4. Island Left (IL) 5. Island Right (IR) 6. Old Narendra Drainage (OND) 7. Mundra Dhipka (MD) 8. Tirupati Balaji Tample (TBT) 9. Jhada Tharae (JT) 10. Housing Board Drainage (HBD) and 11. Ram Tample (RT). To study the seasonal variation of physico- chemical properties and aquatic weed flora, sample were collected regularly during June 2019 to May 2020 at 15 days interval and all samples were immediately brought to the laboratory and determine the parameters within 12-24 hrs of collection. Water samples were collected in air tight glass bottles with proper label according to their name or number.

To determine the physico-chemical properties of collected water sample different water quality parameter was analyzed. The samples were analyzed for physico-chemical properties such as pH, EC (Jackson, 1967), TDS and carbonate \& bicarbonate content (Chopra and Kanwar, 1999) using standard procedure. Different types of aquatic weeds were also collected and identified during study. Weed density (plant $/ \mathrm{m}^{2}$ ) and Weed dry weight $\left(\mathrm{g} / \mathrm{m}^{2}\right)$ was recorded by placing a quadrate $\left(1 \mathrm{~m}^{2}\right)$ at three random spots in each sampling site during every sampling date.

\section{Results and Discussion}

Seasonal variation in physico-chemical properties and floral composition of
Dalpatsagar reservoir was observed regularly and obtained result from analysis of collected sample was present with the help of appropriate table and graphs.

\section{Physico-chemical parameters}

\section{pH}

$\mathrm{pH}$ is a important parameter to determined the water quality of any aquatic ecosystem. The value of $\mathrm{pH}$ is related to the acidity or alkalinity of the water sample. A sample is considered to be acidic if the $\mathrm{pH}$ is below 7.0 while, it is alkaline if the $\mathrm{pH}$ is higher than 7.0. In present study the value of $\mathrm{pH}$ at different location of reservoir was observed in the range between 7.13 and 8.31 in Table 1 . The observed $\mathrm{pH}$ value showed significant seasonal variations with maximum 8.31 in summer season at site of Jhada Tarae (JT) followed by 8.28 at Old Narendra Drainage (OND) and the minimum $\mathrm{pH}$ was recorded 7.13 at site of Mundra Dhipka (MD) in monsoon season. It is also reported that the value of $\mathrm{pH}$ was increased in water bodies is due to higher metabolic activity of autotrophs, because they utilized the available $\mathrm{CO}_{2}$ and liberate $\mathrm{O}_{2}$ thus reducing $\mathrm{H}^{+}$ions concentration significantly Satpathy et al., (2007). During summer season the value of $\mathrm{pH}$ is higher due to due to utilization of bicarbonate and carbonate buffer system in Aquatic condition (Ramakrishana, 2003; Mehrotra, 1988).

\section{EC}

Electrical conductivity of water is indicate the presence of salt concentration in water, it is the capacity of water to conduct electricity and used as a tool to indicating the purity of water. It was discovered from present study that the value of EC of water is ranged between $0.21 \mathrm{dSm}^{-1}$ to $0.47 \mathrm{dSm}^{-1}$ (Table 2). At Dalpatsagar reservoir it is recorded that the 
value of EC is higher $0.47 \mathrm{dSm}^{-1}$ at Jhada Tarae (JT) during summer season followed by $0.45 \mathrm{dSm}^{-1}$ at Ram Temple site. While the minimum EC was recorded during monsoon season as $0.21 \mathrm{dSm}^{-1}$ at Housing Board Drainage (HBD) site. Gupta and Paul (2013) also observed the maximum electric conductivity (EC) during summer season and in monsoon season conductivity is gradually decrease is due to increased volume of water as a result of frequent rain that caused a decline in salt concentration. The value of EC is positively correlated with the $\mathrm{pH}$ value, as $\mathrm{pH}$ value was increases the value of EC also increases significantly (Guptaa, 2009).

Table.1 Seasonal Variation in $\mathrm{pH}$ of Water sample at Dalpatsagar reservoir

\begin{tabular}{|l|l|l|l|l|l|l|l|l|l|l|l|}
\hline Season & CT & SB & BB & IL & IR & OND & MD & TBT & JT & HBD & RT \\
\hline Monsoon & 7.39 & 7.42 & 7.44 & 7.56 & 7.54 & 7.52 & 7.43 & 7.54 & 7.60 & 7.51 & 7.45 \\
\hline Winter & 7.40 & 7.40 & 7.63 & 7.90 & 7.66 & 7.73 & 7.57 & 7.47 & 7.45 & 7.36 & 7.55 \\
\hline Summer & 8.05 & 8.27 & 8.15 & 8.08 & 8.25 & 8.28 & 8.27 & 8.04 & 8.31 & 8.19 & 7.84 \\
\hline Min. & 7.39 & 7.40 & 7.44 & 7.56 & 7.54 & 7.52 & 7.43 & 7.47 & 7.45 & 7.36 & 7.45 \\
\hline Max. & 8.05 & 8.27 & 8.15 & 8.08 & 8.25 & 8.28 & 8.27 & 8.04 & 8.31 & 8.19 & 7.84 \\
\hline Mean & 7.61 & 7.70 & 7.74 & 7.85 & 7.82 & 7.84 & 7.76 & 7.68 & 7.78 & 7.69 & 7.62 \\
\hline Sd & 0.38 & 0.50 & 0.37 & 0.26 & 0.38 & 0.39 & 0.45 & 0.31 & 0.46 & 0.45 & 0.20 \\
\hline CV & 4.95 & 6.47 & 4.74 & 3.37 & 4.86 & 4.98 & 5.76 & 4.03 & 5.89 & 5.80 & 2.63 \\
\hline
\end{tabular}

Table.2 Seasonal Variation in EC $\left(\mathrm{dSm}^{-1}\right)$ of Water sample at Dalpatsagar reservoir

\begin{tabular}{|l|c|c|c|c|c|c|c|c|c|c|c|}
\hline Season & CT & SB & BB & IL & IR & OND & MD & TBT & JT & HBD & RT \\
\hline Monsoon & 0.28 & 0.27 & 0.29 & 0.34 & 0.31 & 0.33 & 0.24 & 0.27 & 0.26 & 0.21 & 0.31 \\
\hline Winter & 0.36 & 0.36 & 0.34 & 0.37 & 0.37 & 0.35 & 0.35 & 0.34 & 0.33 & 0.33 & 0.32 \\
\hline Summer & 0.42 & 0.42 & 0.44 & 0.40 & 0.40 & 0.39 & 0.44 & 0.43 & 0.47 & 0.38 & 0.45 \\
\hline Min. & 0.28 & 0.27 & 0.29 & 0.34 & 0.31 & 0.33 & 0.24 & 0.27 & 0.26 & 0.21 & 0.31 \\
\hline Max. & 0.42 & 0.42 & 0.44 & 0.40 & 0.40 & 0.39 & 0.44 & 0.43 & 0.47 & 0.38 & 0.45 \\
\hline Mean & 0.35 & 0.35 & 0.36 & 0.37 & 0.36 & 0.35 & 0.34 & 0.35 & 0.36 & 0.31 & 0.36 \\
\hline Sd & 0.04 & 0.03 & 0.06 & 0.03 & 0.03 & 0.03 & 0.04 & 0.05 & 0.07 & 0.03 & 0.07 \\
\hline CV & 11.41 & 8.49 & 15.89 & 8.47 & 8.77 & 7.68 & 12.46 & 13.73 & 20.50 & 8.42 & 18.24 \\
\hline
\end{tabular}

Table.3 Seasonal Variation in TDS (mg/l) of water sample at Dalpatsagar reservoir

\begin{tabular}{|l|r|r|r|r|r|r|r|r|r|r|r|}
\hline Season & \multicolumn{1}{c|}{ CT } & \multicolumn{1}{c|}{ SB } & \multicolumn{1}{c|}{ BB } & \multicolumn{1}{|c|}{ IL } & \multicolumn{1}{c|}{ IR } & \multicolumn{1}{c|}{ OND } & \multicolumn{1}{c|}{ MD } & \multicolumn{1}{c|}{ TBT } & \multicolumn{1}{c|}{ JT } & \multicolumn{1}{c|}{ HBD } & \multicolumn{1}{c|}{ RT } \\
\hline Monsoon & 230.40 & 229.60 & 216.80 & 235.20 & 233.60 & 222.40 & 226.40 & 216.80 & 213.60 & 213.60 & 202.40 \\
\hline Winter & 223.20 & 257.60 & 226.40 & 217.60 & 218.40 & 256.00 & 243.20 & 231.20 & 231.20 & 239.20 & 238.40 \\
\hline Summer & 271.20 & 265.60 & 284.00 & 257.60 & 258.40 & 247.20 & 280.00 & 275.20 & 301.60 & 244.80 & 285.60 \\
\hline Min. & 223.20 & 229.60 & 216.80 & 217.60 & 218.40 & 222.40 & 226.40 & 216.80 & 213.60 & 213.60 & 202.40 \\
\hline Max. & 271.20 & 265.60 & 284.00 & 257.60 & 258.40 & 256.00 & 280.00 & 275.20 & 301.60 & 244.80 & 285.60 \\
\hline Mean & 241.60 & 250.93 & 242.40 & 236.80 & 236.80 & 241.87 & 249.87 & 241.07 & 248.80 & 232.53 & 242.13 \\
\hline Sd & 25.89 & 18.90 & 36.35 & 20.05 & 20.19 & 17.42 & 27.41 & 30.42 & 46.57 & 16.63 & 41.73 \\
\hline CV & 10.71 & 7.53 & 14.99 & 8.47 & 8.53 & 7.20 & 10.97 & 12.62 & 18.72 & 7.15 & 17.23 \\
\hline
\end{tabular}


Table.4 Seasonal Variation of $\mathrm{CO}_{3}(\mathrm{mg} / \mathrm{l})$ content in water sample at Dalpatsagar reservoir

\begin{tabular}{|c|c|c|c|c|c|c|c|c|c|c|c|}
\hline Season & CT & SB & BB & IL & IR & OND & MD & TBT & JT & HBD & RT \\
\hline Monsoon & 54.76 & 58.51 & 57.38 & 52.88 & 61.51 & 55.51 & 54.38 & 56.26 & 61.88 & 51.76 & 54.01 \\
\hline Winter & 60.38 & 81.76 & 52.51 & 57.76 & 67.13 & 69.01 & 54.38 & 51.76 & 68.26 & 53.63 & 66.76 \\
\hline Summer & 54.01 & 48.76 & 57.01 & 55.13 & 57.76 & 55.51 & 51.76 & 48.01 & 56.63 & 49.88 & 57.01 \\
\hline Min. & 54.01 & 48.76 & 52.51 & 52.88 & 57.76 & 55.51 & 51.76 & 48.01 & 56.63 & 49.88 & 54.01 \\
\hline Max. & 60.38 & 81.76 & 57.38 & 57.76 & 67.13 & 69.01 & 54.38 & 56.26 & 68.26 & 53.63 & 66.76 \\
\hline Mean & 56.38 & 63.01 & 55.63 & 55.26 & 62.13 & 60.01 & 53.51 & 52.01 & 62.26 & 51.76 & 59.26 \\
\hline Sd & 3.48 & 16.96 & 2.71 & 2.44 & 4.72 & 7.80 & 1.52 & 4.13 & 5.82 & 1.88 & 6.67 \\
\hline $\mathrm{CV}$ & 6.18 & 26.91 & 4.88 & 4.42 & 7.60 & 12.99 & 2.83 & 7.94 & 9.35 & 3.62 & 11.25 \\
\hline
\end{tabular}

Table.5 Seasonal Variation of $\mathrm{HCO}_{3}(\mathrm{mg} / \mathrm{l})$ content in water sample at Dalpatsagar reservoir

\begin{tabular}{|l|r|r|r|r|r|r|r|r|r|r|r|}
\hline Season & \multicolumn{1}{|c|}{ CT } & \multicolumn{1}{|c|}{ SB } & \multicolumn{1}{|c|}{ BB } & \multicolumn{1}{|c|}{ IL } & \multicolumn{1}{c|}{ IR } & \multicolumn{1}{c|}{ OND } & \multicolumn{1}{c|}{ MD } & \multicolumn{1}{c|}{ TBT } & \multicolumn{1}{c|}{ JT } & \multicolumn{1}{c|}{ HBD } & RT \\
\hline Monsoon & 178.47 & 175.42 & 147.96 & 180.00 & 213.56 & 189.15 & 166.27 & 189.15 & 164.74 & 195.25 & 173.90 \\
\hline Winter & 257.79 & 305.08 & 259.32 & 227.28 & 306.61 & 239.49 & 228.81 & 200.59 & 231.86 & 216.61 & 277.62 \\
\hline Summer & 175.42 & 164.74 & 172.37 & 166.27 & 176.95 & 173.90 & 161.69 & 190.68 & 125.85 & 151.01 & 167.79 \\
\hline Min. & 175.42 & 164.74 & 147.96 & 166.27 & 176.95 & 173.90 & 161.69 & 189.15 & 125.85 & 151.01 & 167.79 \\
\hline Max. & 257.79 & 305.08 & 259.32 & 227.28 & 306.61 & 239.49 & 228.81 & 200.59 & 231.86 & 216.61 & 277.62 \\
\hline Mean & 203.90 & 215.08 & 193.22 & 191.18 & 232.37 & 200.84 & 185.59 & 193.47 & 174.15 & 187.62 & 206.44 \\
\hline Sd & 46.70 & 78.12 & 58.53 & 32.01 & 66.85 & 34.32 & 37.50 & 6.21 & 53.63 & 33.45 & 61.72 \\
\hline CV & 22.90 & 36.32 & 30.29 & 16.74 & 28.77 & 17.09 & 20.21 & 3.21 & 30.80 & 17.83 & 29.90 \\
\hline
\end{tabular}

Table.6 Major dominant aquatic weed species found in Dalpatsagar reservoir

\begin{tabular}{|c|c|c|c|}
\hline S.No. & Scientific Name & Family & Common Name \\
\hline 1 & Eichhornia crassipes (mart.) solms & Pontederiaceae & Water hyacinth \\
\hline 2 & Pistia stratiotes & Araceae & Water lettuce \\
\hline 3 & Ipomoea aquatica Forssk & Convolvulaceae & Swanry Morning glory \\
\hline 4 & Nelumbo nucifera Gaertn. & Nelumbonaceae & Indian lotus \\
\hline 5 & Alternanthera philoxeroides(Mart.)Griseb. & Amaranthaceae & Alligator weed \\
\hline 6 & Nymphaea rubra Roxb. ex Andrews & Nymphaeaceae & Red WaterLily \\
\hline 7 & Cyperus javanicus Houtt. Houttuyn & Cyperaceae & Javanese Flat Sadge \\
\hline 8 & Nymphaea alba L., & Nymphaeaceae & White water lily \\
\hline 9 & Nymphoides indica (L.) Kuntz & Menyanthaceae & Yellow Waterlily \\
\hline 10 & Echinodorus grisebachii Small & Alismataceae & Amazon sword plant \\
\hline 11 & Oxalis carniculata L. & Oxalidaceae & Creeping wood sorrel \\
\hline 12 & Ipomoea sagitttifolia & Convolvulaceae & Morning Glory \\
\hline 13 & Ipomoea carnea Jace. & Convolvulaceae & Pink morning glory \\
\hline 14 & Oryza nivara S.D. Sharma \& Shastry & Poaceae & Indian wild rice \\
\hline 15 & Alternanthera sessilis (L.) & Amaranthaceae & Sessile joyweed \\
\hline 16 & Potamogaton crispus L. & Potamogetonaceae & Curled pondweed \\
\hline 17 & Lamna minor L. & Araceae & Common duckweed \\
\hline 18 & Potamegaton amplifolius Tuckerman & Potamogetonaceae & Largeleaf pondweed \\
\hline 19 & Ceratophylum demerus $\mathrm{L}$. & Ceratophyllaceae & Hornwort/Coons Tail \\
\hline 20 & Hydrilla verticillata & Hydrocharitaceae & Water thyme \\
\hline
\end{tabular}


Fig.1 Weed Density in different month at Dalpatsagar reservoir

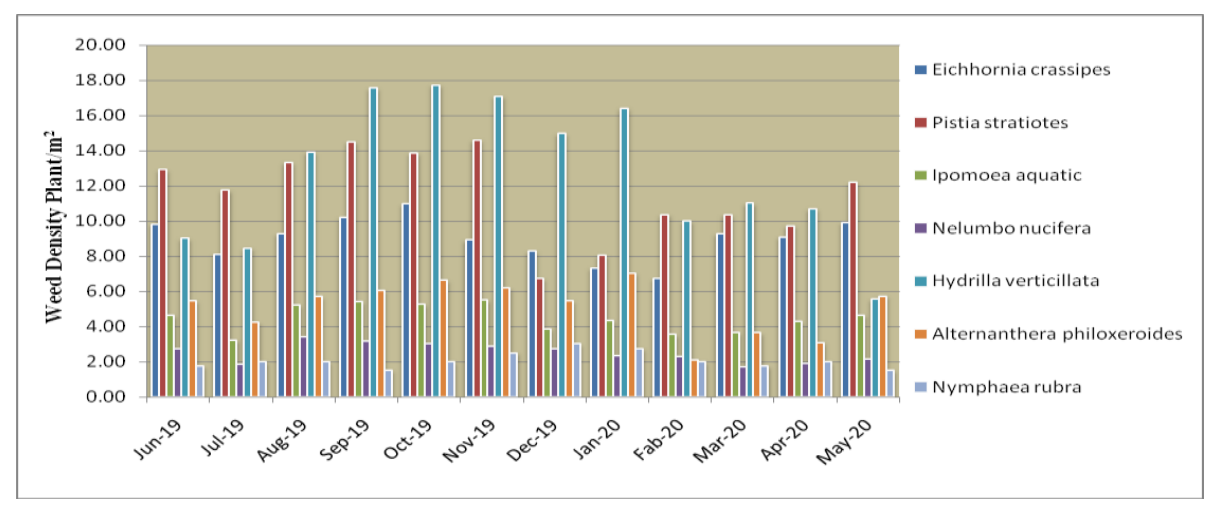

Fig.2 Weed dry weight in different month at Dalpatsagar reservoir

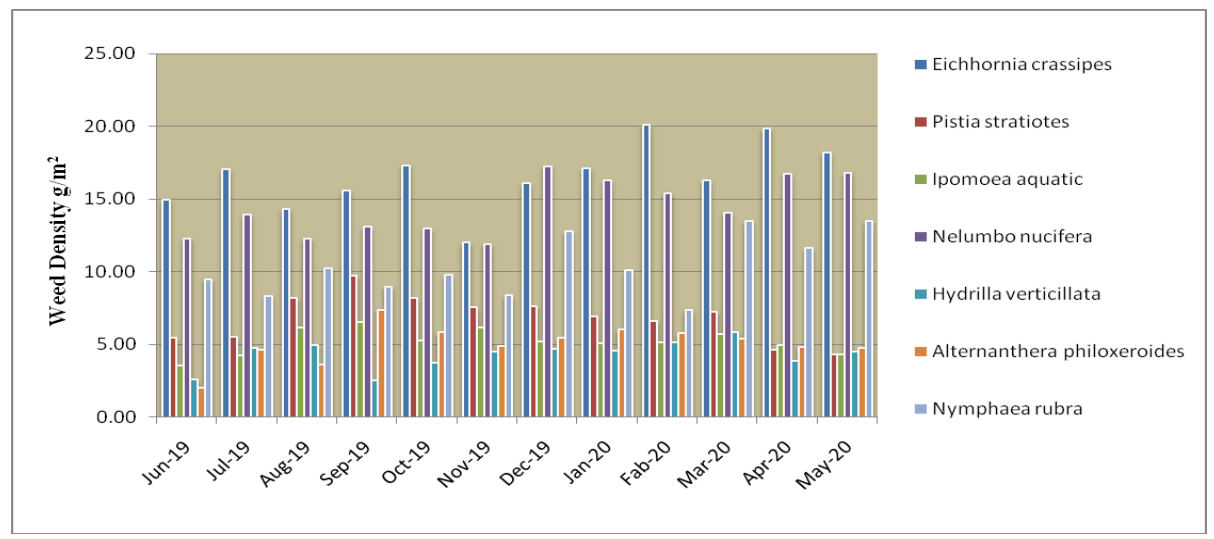

\section{Total Dissolved Solid (TDS)}

Total Dissolved Solid (TDS) is act as a indicator of dissolved substances in water. The total dissolved solids are somehow correlated with $\mathrm{pH}$ and $\mathrm{EC}$ that depends on escaping of acid forming materials, external dissolved salt and evaporation rate. Observed data on TDS of Dalpatsagar reservoir was significantly differed as time passed with seasonal variations. The TDS values obtained from present study ranged between $202.40-301.60 \mathrm{mg} / \mathrm{L}$ With highly significant seasonal variations (Table 3 ). The value of TDS was maximum $301.60 \mathrm{mg} / \mathrm{L}$ at Jhada Tarae (JT) in summer season followed by $285.60 \mathrm{mg} / \mathrm{L}$ at Ram Temple (RT) site and the minimum TDS $218.40 \mathrm{mg} / \mathrm{l}$ at Island Right (IR) and $202.40 \mathrm{mg} / \mathrm{l}$ at Jhada Tarae (JT) was recorded during winter and monsoon season respectively. The maximum TDS value was recorded during summer season is may be correlated to the increased water temperatures which lead to increase the evaporation rate as well as increase the dissolved solids in water and the minimum value of TDS at reservoir were evident with the high water level in post monsoon due to the excessive dilution, stagnation and low rate of evaporation (Mathur et al., 2008). Similar study on TDS was quoted by Patil et al., 2011.

\section{Carbonate $\left(\mathrm{CO}_{3}\right)$ and Bicarbonate $\left(\mathrm{HCO}_{3}\right)$ Content}

In freshwaters reservoir, occurrence of $\mathrm{CO}_{3}$ and $\mathrm{HCO}_{3}$ ions are the result of removal of $\mathrm{CO}_{2}$ produced by the process of photosynthesis activity or by dissolved 
carbonate or bicarbonate salts in the water. In pond ecosystem higher value of $\mathrm{pH}$ is due to reduced photosynthetic activity and assimilation of $\mathrm{CO}_{2}$ and Bicarbonate during in summer season. During study period the amount of carbonate $\left(\mathrm{CO}_{3}\right)$ was recorded in the range of $48.01 \mathrm{mg} / \mathrm{L}$ to $81.76 \mathrm{mg} / \mathrm{L}$ at different location of reservoir (Tbale 4). The higher carbonate content was noted in winter season as $81.76 \mathrm{mg} / \mathrm{L}$ at Shaan Baule (SB) followed by $69.01 \mathrm{mg} / \mathrm{L}$ at Old Narendra Drainage (OND) (Table 4). Meanwhile minimum carbonate $\left(\mathrm{CO}_{3}\right)$ content 48.01 $\mathrm{mg} / \mathrm{L}$ was recorded during summer season at Tirupati Balaji Temple site and in other location amount of $\mathrm{CO}_{3}$ was quite similar during summer season. The reason behind the higher $\mathrm{CO}_{3}$ content during winter may be due to the uptake of free carbon dioxide by aquatic microphytes macrophytes (Sharma, 2002 and Singh, 2004) at all the study sites. During the same period bicarbonate $\left(\mathrm{HCO}_{3}\right)$ content in the water of different location was varied from $125.85 \mathrm{mg} / \mathrm{L}$ to $306.61 \mathrm{mg} / \mathrm{L}$ (Table 5). The amount of $\mathrm{HCO}_{3}$ was recorded similar tread as carbonate content. The maximum amount of bicarbonate $\left(\mathrm{HCO}_{3}\right)$ $306.61 \mathrm{mg} / \mathrm{L}$ during winter season at island Right (IR) followed by $305.08 \mathrm{mg} / \mathrm{L}$ at Shaan Baule site. In summer season the amount of bicarbonate was observed significantly less 125.85 at Jhada Tarae (JT) location. The amount bicarbonate was recorded minimum during summer may be due to its maximum utilization by photosynthetic activity of micro and macrophytes (Kaul et al., 1980 and Naik et al., 2015). In general the higher carbonate and bicarbonate is due to the accumulated organic matter which is produced from decay and decomposition of vegetation and domestic sewage (Shrinivas and Aruna 2018).

\section{Weed dynamics in Dalpatsagar reservoir}

Dalpatsagar reservoir is severely infected with different aquatic weed species in throughout the year and continuously affects the water quality and pond ecosystem. The floristic composition of aquatic macrophytes was found different in different seasons, during the study period 20 major weed species was observed in the different site of Dalpatsagar reservoir and each of them belonging to the different family. Out of 20 major weed species 7 dominant aquatic weed species Eichhornia crassipes (mart.) solms, Pistia stratiote, Ipomoea aquatic Forssk, Nelumbo nucifera Gaertn., Alternanthera philoxeroides (Mart.) Griseb., Nymphaea rubra Roxb. ex Andrews. And Hydrilla verticillata were found throughout the years which highly affected the pond ecosystem, similar weed species also recorded by Pradhan and Kumar 2019.

The list of commonly found weed plants seen in different sampling sites of Dalpatsagar reservoir has been shown in the Table 6 .

\section{Weed density}

Fig. 1 shows the monthly variation of aquatic weed density throughout the year with different environmental condition at Dalpatsagar reservoir. The weed density is measure of number of weed plant in per $\mathrm{m}^{2}$. During present study out of 20 major weed species 7 most dominant aquatic weed species are considered namely Eichhornia crassipes, Pistia stratiote, Ipomoea aquatic, Nelumbo nucifera, Alternanthera philoxeroides, Nymphaea rubra and Hydrilla verticillata were found throughout the year. Among of these weed species the maximum weed density was recorded 5.55 to 17.73 with Hydrilla verticillata in throughout the year while it is higher during September to January month followed by Pistia stratiote which was approximately 13.00 and Eichhornia crassipes was nearly 8.0 to 10 in throughout the year. Other weed species Nelumbo nucifera and Nymphaea rubra had large size 
leaves they also found 2 to 3 plant per $\mathrm{m}^{2}$ and comparatively density of Alternanthera philoxeroides and Ipomoea aquatica also found throughout the year. It is observed that the highest weed density was recorded after post monsoon season (Oct-19 to Feb-20) during one year of observation.

\section{Weed dry weight}

Weed dry weight was recorded in $\mathrm{g} / \mathrm{m}^{2}$ during the study period (Fig. 2) at Dalpatsagar reservoir. The highest weed dry matter was observed with Eichhornia crassipes 14.28 to $20.07 \mathrm{~g} / \mathrm{m}^{2}$ followed by Nelumbo nucifera which is 12.24 to 17.24 and Nymphaea rubra 7.35 to $13.49 \mathrm{~g} / \mathrm{m}^{2}$ during throughout the year. The weed dry matter of Nelumbo nucifera and Nymphaea rubra was quiet higher due to their large leaves size attain maximum weight during study period. Among of this weed species other weed species Pistia stratiote, Ipomoea aquatica, Alternanthera philoxeroides and Hydrilla verticillata also contribute significant amount of weed dry weight at throughout the year. Overall highest weed dry weight was as similar to the density of weeds because they are positively correlated to each other, as the weed density increases weed dry weight was also increases significantly.

In conclusion the physico-chemical properties of Dalpatsagar reservoir at different location was found significantly difference with different season and influenced the changing water quality as well as distribution and abundance of aquatic macrophytes. The value of $\mathrm{pH}, \mathrm{EC}$ and TDS was highest during summer season while The $\mathrm{CO}_{3}$ and $\mathrm{HCO}_{3}$ content was maximum during post monsoon season respectively. The aquatic weed dynamics was found with different in different seasons. Dalpatsagar reservoir is severely infested with 20 different major aquatic weed species but the most dominant 7 weed species named as Eichhornia crassipes, Pistia stratiote, Ipomoea aquatic, Nelumbo nucifera, Alternanthera philoxeroides, Nymphaea rubra And Hydrilla verticillata were found throughout the years and affecte the pond ecosystem continuously.

\section{References}

Banner, A. and MacKenzie, W. 2000. The ecology of wetland ecosystem. 45 extension note. Ministry of Forest Research Program, Victoria, BC.

Chopra S. L. and Kanwar J. S. 1999. Analytical Agricultural Chemistry, Kalyani Publishers, New Delhi. 4th Ed. Pp. 280-283.

Gopal, B. and Sharma, K.P. 1981. Water Hyacinth (Eichhornia Crassipes) the Most Troublesome Weeds of the World. Hindasia Publisher, New Delhi, 129 p.

Gupta, D. P., Sunita and J. P. Saharan, 2009. Physiochemical Analysis of Ground Water of Selected Area of Kaithal City (Haryana) India, Researcher, 1(2), pp 15.

Gupta, T., and Paul, M. 2013. The seasonal variation in the ionic composition of pond water of Lumding, Assam, India. Currently World Environment, 8(1): 127-131.

Jackson, M.L. 1973. Soil Chemical Analysis, Prenctice Hall ofIndia Pvt. Ltd., New Delhi, pp. 183-204.

Kaul, V., Trisal, C.L. and Kaul, S. 1980. Mineral removal potential of some macrophytes in two lakes of Kashmir. Journal of Indian Botanical Society, 55:113-123.

Mathur, P., Agarwal, S. and Nag, M. 2008. Assessment of physico-chemical characteristics and suggested restoration measures for Pushkar Lake, Ajmer Rajasthan, India. Proceedings of Taal 2007, The 12th World Lake Conference, p. $1518-1529$. 
Mehrotra, S. 1988. Benthic studies on Lal Sagar Reservoir with special reference to macrobenthic fauna. PH. D. Thesis, University of Jodhapur, Rajastan.

Mustapha, M.K. and Osotosho, J.S., 2005. An Assessment of the physico-chemical Properties of Moro Lake, Kwara state Nigeria, African Journal of Applied Zoology \& Environment Biology,Vol.7 P.73-77.

Naik, G., Rashid, M. and Balkhi, M.H. 2015. Changes in Physico-chemical parameters at different sites of Manasbal Lake of Kashmir, India. Fish Aquatic J., 6:148 doi:10.4172/2150-3508.1000148.

Patil, J. V., Ekhande, A. P., and Padate, G. S. 2011. Study of Lotus Lake: its abiotic factors their correlation with reference to seasonal changes and altitude. Annals of Biological Research Vol.2 No.4 pp.44-56 ref.83.

Pradhan, A. and Kumar, S. 2019. Aquatic weeds management through chemical and manual integration to reduce cost by manual removal alone and its effect on water quality. Indian Journal of Weed Science 51(2): 183-187, 201

Pradhan, A. and Patil, S.K. 2017. Conference: Wetland Wealth of Chhattisgarh Dalpatsagar, Chhattisgarh State Planning Commission Raipur.

Prakash, K.L. and Somashekar, R.K. 2006. Groundwater quality - Assessment on Anekal Taluk, Bangalore Urban district,
India. Journal of Environmental Biology 27(4):633-7

Ramakrishnan, N. 2003. Bio-Monitoring approaches for water quality Assessment in two Water Bodies at Tiruvannamalal, TamilNadu. Proc. of the third Inter. Conf. on Env. and Health, Chennai. 15-17

Satpathy, K.K., Mohanty, A.K., Sahu, G., Prasad, M.V.R., Venkatesan, R., Natesan, U. and Rajan, M. 2007. On the occurrence of Trichodesmium erythraeum (Ehr.) bloom in the coastal waters of Kalpakkam, east coast of India. Indian Journal of Science and Technology Vol.1 No.2

Sharma, S. 2002. Sudies on the impact of anthropogenic influences on the ecology of Gharana Wetland, Jammu. Ph.D Thesis , University of Jammu.

Singh, B.K. 2004. Biodiversity, conservation and management. Mangal deep Publications, Jaipur, India.

Srinivas, M. and Aruna, M. 2018. Physicochemical analysis of a lake, Erea Cheruvu in Siddipet District of Telangana State, India. International Journal of Recent Scientific Research Vol. 9, Issue, 10(E), pp. 29420-29425.

Sushilkumar. 2011. Biological based chemical integration for early control of water hyacinth. Indian Journal of Weed Science 43 (3\&4): 211-214.

\section{How to cite this article:}

Subhash Soni, A. Pradhan and Vikky Kumar. 2020. Assessment of Physico-chemical Properties and Weed Dynamics of Dalpatsagar Reservoir, Jagdalpur. Int.J.Curr.Microbiol.App.Sci. 9(11): 2353-2361. doi: https://doi.org/10.20546/ijcmas.2020.911.282 